\title{
Global shifts caused by the rise of anchor countries
}

\begin{abstract}
Recently a group of large developing countries started to emerge as important drivers of regional, and in some cases even global, change. "Anchor countries" are the largest economies of their respective home regions. Their rise implies a power shift in different spheres of economy and politics and brings about new patterns in the organization of global space. We analyse this shift with regard to the global economic order and to global security policy. Furthermore, we explore how the enhanced economic and military relevance of anchor countries is reflected in global governance institutions.
\end{abstract}

\section{Anchor countries - a new concept to capture the regional and global role of "emerging economies"}

During the last centuries, global economic and political power has been concentrated in the West. Industrialization and trade enabled European nations to accumulate capital in an unprecedented way and constitute themselves as truly global hegemonic powers. Subsequently, the rise of the United States of America challenged European supremacy and the US established themselves as the largest and most innovative economy and new political as well as military hegemon. The world economic and political order became dominated by the transatlantic West. Only after the Second World War, Japan emerged as a third driving force of the world economy. During most of the post-war period, global economic power was thus heavily concentrated in the Triad region consisting of North America, Europe and Japan (OHMAE 1985). Almost all multinational corporations were based in the Triad, and almost the totality of technological innovations emerged here. The G7 (now G8, after the inclusion of Russia) was the largely undisputed club of the economically powerful nations. After the Second World War the Soviet Union also emerged as a military contender of the US, but the inefficiency of its economic system and collapse in the late 1980s and early 1990s halt- ed its economic ascendance. Following the break-up of the Soviet Union, the USA emerged as the only superpower in global governance, especially due to its military supremacy, whereas economic power remained concentrated in the Triad.

Patterns of global economic geography strongly reflected this structure. Global maps of production, distribution of knowledge assets (e.g. global top universities, patents, leading multinationals), trade and finance flows, labour productivity, per capita income, energy consumption and many other topics related to economic development all revealed similar patterns of Triad dominance. Concentration of economic power was mirrored in political influence, e.g. representation in key institutions of global governance, such as the Bretton Woods institutions and the UN Security Council.

This situation is now changing fundamentally. A new group of countries from the "South" is emerging, with huge implications for the global economy and international politics. Using the terminology proposed by STAMM (2004) we call them "anchor countries". Anchor countries comprise the largest economies of each of the developing regions as defined by the World Bank plus those secondary economies that account for at least $20 \%$ of the remaining regional GDP - or, to put it more simply, the 
largest economies of the non-Triad regions. 15 countries are classified as anchor countries: Argentina, Brazil, China, Egypt, India, Indonesia, Iran, Mexico, Nigeria, Pakistan, Russia, SaudiArabia, South Africa, Thailand, and Turkey. ${ }^{1}$

Emerging economies from the "South" are commonly termed "threshold countries" (Schwellenländer) or "Newly Industrializing Countries". None of these terms however is appropriate to capture the increasing role of these countries with regard to global economic and political power shifts that the anchor country concept describes. With regard to "threshold countries", STAMm (2004) rightly points out that the group of countries which are "at the threshold" to achieve a typical OECD profile with regard to human development, economic competitiveness, governance and environmental performance barely overlaps with the anchor country group. In fact, five out of 15 anchor countries are classified as lower-middleincome (Egypt, Indonesia, China, Thailand and Iran) and three even as low-income countries (Nigeria, Pakistan and India). Their high aggregate GDP is only due to their huge popula- tion size. If we take the Human Development Index as a more comprehensive measure of development, only four of the 15 anchor countries rank among the first 70 countries. According to Stamm's definition, only two anchor countries - Brazil and Mexico - can also be considered to be "at the development threshold" (see Fig. 1). The other fairly advanced countries tend to be relatively small, with little weight in the regional or world economy.

The anchor country concept highlights economic weight in regional and global terms, regardless of the countries' level of development. The anchor countries' relative size in the regional economy tends to generate strong economic and political spillovers into the respective regions and also goes along with a significant regional - sometimes also global political role. ${ }^{2}$ The anchor country concept thus emphasizes the fact that a number of developing countries are becoming strong regional drivers and in some cases even gain significant influence on global affairs. We assume that this gain of influence is causing a global power shift.

Fig. 1: Anchor and threshold countries

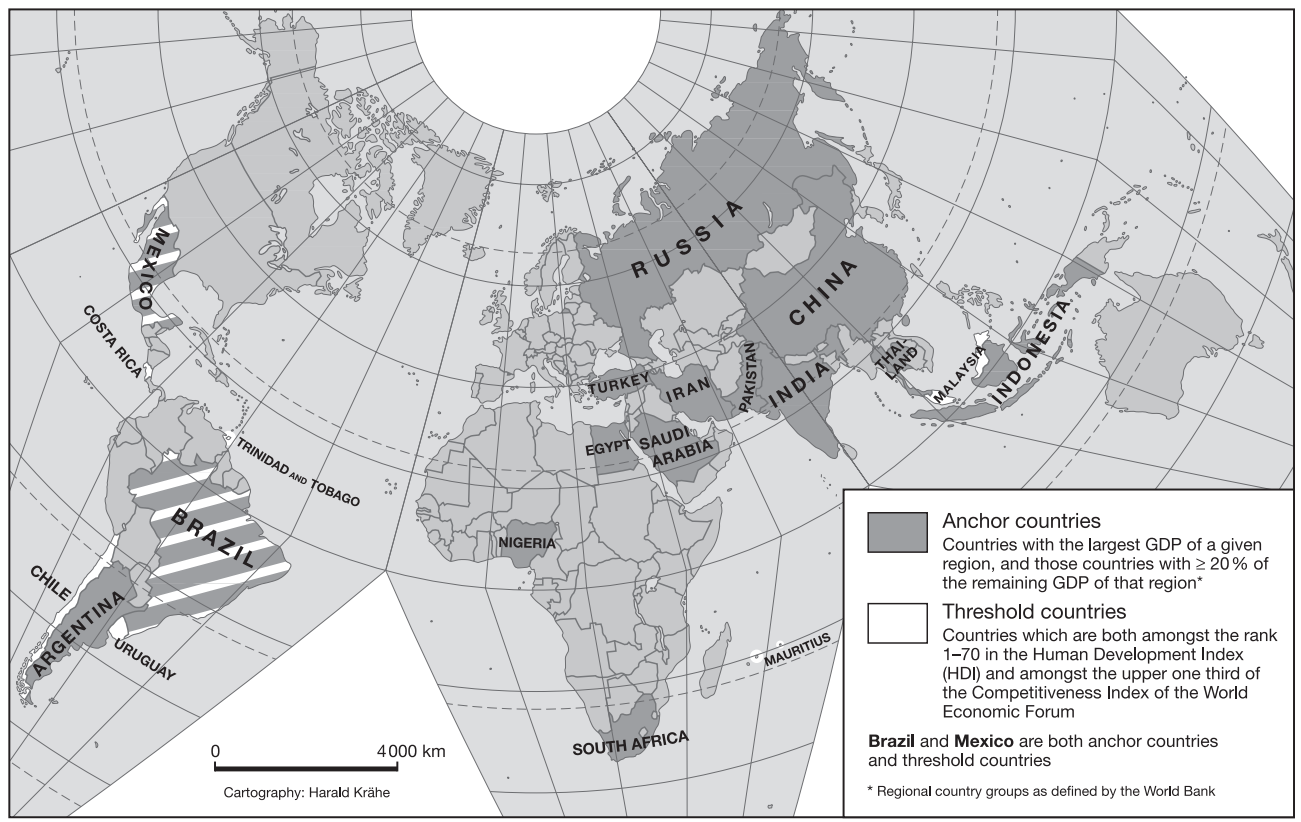

Source: own draft 
The current global power shift is unprecedented in history. Although the history of economic development has seen many cases of growth and decline (e.g. LANDES 1998) the recent rise of a group of new powers from the developing world is unique due to a combination of two factors: Extraordinarily high economic growth (particularly in China and recently also in India) and enormous size in population and geographic terms. In 2007, China and India alone accounted for $37.1 \%$ of the global population (Deutsche Stiftung Weltbevölkerung 2007). Hence we are witnessing a marked increase of per capita GDP income of several billion people and, as a result, much increased consumption, higher education, new consumption patterns, increasing carbon emissions. The effects on the rest of the world are much larger than those of previous catch-up processes, e.g. those of Ireland or South Korea. Analytically we may distinguish three characteristics that set anchor countries apart from smaller developing countries (see Fig. 2):

1. Significant country size effects. Anchor countries are defined by the size of their economies relative to their respective world region - an indicator which strongly correlates with large populations and territories. As a consequence, internal developments in these large countries contribute significantly to the ability or inability to solve regional and global problems. Whether the world will, for example, be able to achieve the Millennium Development Goals, e.g. to halve poverty by the year 2015 , strongly depends on developments within the anchor countries. In 2007, China and India alone accounted for $47.2 \%$ of the global poor, and the 15 anchor countries together for $64.4 \%$ (own calculation based on UNDP 2007). China shifted 77 million inhabitants out of poverty between 2003 and 2007 (ibid.), thereby making a strong contribution to global poverty reduction - in contrast to Africa and Latin America which are, on the whole, not on track to achieve their poverty reduction targets (United Nations 2006). Likewise, successful biodiversity protection depends to a large extent on the national policies adopted in ecologically highly diverse and species-rich anchor countries like Brazil and Indonesia.

2. Considerable spillover effects beyond the countries' boundaries. Any action that is ta- ken in a given country somehow effects other countries. If countries increase their greenhouse gas emissions they contribute to global warming; if they succeed in fighting infectious diseases within their boundaries, they automatically reduce the risks for other countries; if they invest in military expenditure, other countries may feel the need to adapt their own expenditure to counterbalance the increase of their neighbour's material power basis. Spillovers from anchor countries - both positive and negative - tend to be much larger than those emanating from small countries. China in particular impacts strongly on the rest of the world, e.g. via its supply of cheap manufactures that benefit consumers worldwide and seriously threaten competitors in other parts of the world; via its demand for natural resources that drives oil and other commodity prices up; via its increasing carbon emissions; and via its foreign exchange reserves that are crucial to finance the US trade deficit and keep the world economy afloat. Likewise, the financial crises that affect large parts of the developing world started off from anchor countries, in particular from Mexico in 1982 and again 1994/95, and from Thailand and Indonesia in 1997.

3. Voice in global and/or regional governance. Given their increasing share in the global economy and their stronger regional role, some of the most important anchor countries have all stepped up their foreign policy efforts and claim a stronger role in arenas and institutions of global governance. At the regional level, they are mostly the most powerful agenda-setters in the relevant institutions. Brazil, Argentina and Mexico for example occupy key roles in the InterAmerican Development Bank, the former two also in the Organization of American States. Brazil in particular is an important antagonist of the US with regard to the envisaged Free Trade Area of the Americas, where differences between both countries have hampered the integration process (SCHIRM 2007, 7 ff.). Likewise, Nigeria is an important factor in economic and political processes in Sub-Saharan Africa, e.g. in the Economic Community of West African States (ECOWAS), the initiative New Partnership for Africa's Development, and in peacekeeping missions. While most anchor countries can mainly be considered as regional 
leading powers, some claim more voice in global governance. In addition to Russia, which has already been accepted as a G8 member, five other anchor countries - China, India, Brazil, Mexico and South Africa can be considered to have a significant voice in global institutions. In 2007 these five countries were invited to the G8 summit in Heiligendamm as especially important partners for dialogue, although not (yet) formally admitted to this "club". The same countries are actively involved in a number of other global institutions. In addition, all of them have country size effects that affect not only their own region but also global developments (see Fig. 2). Of course, China and India stand out in this respect.

In the following we focus our analysis on the five most influential anchor countries: Brazil, China, India, Mexico and South Africa. ${ }^{3}$ A number of global problems cannot be solved without their political support (COOPER et al. 2006). Tab. 1 provides a synopsis of the relevance of these anchor countries with regard to some of the most important global problems and shows how they contribute to, or in some cases hamper, global policy-making and the work of global institutions that deal with these problems. We have opted here for an illustrative study of two policy fields where the material power base is clearly shifting towards anchor countries, namely 1) the global economic order and 2) global security policy. Furthermore, we explore how the increased "material relevance" is mirrored in increasing claims to power and greater influence in key arenas and institutions of global governance.

\section{The role of anchor countries as new economic powerhouses}

Anchor countries are among the most dynamic economies of the world. As they are in most cases at quite low levels of economic development, economic reforms result in much higher rates of economic growth. Since 2003 China, India, Argentina, Nigeria, Pakistan, Russia, and Turkey all grow at average rates higher than $7 \%$ per annum. Indonesia, Iran, Thailand and Saudi Arabia are slightly less dynamic, but still grow at rates above $5 \%$ (World Bank 2007). According to projections, anchor coun-

Fig. 2: Characteristics of anchor countries

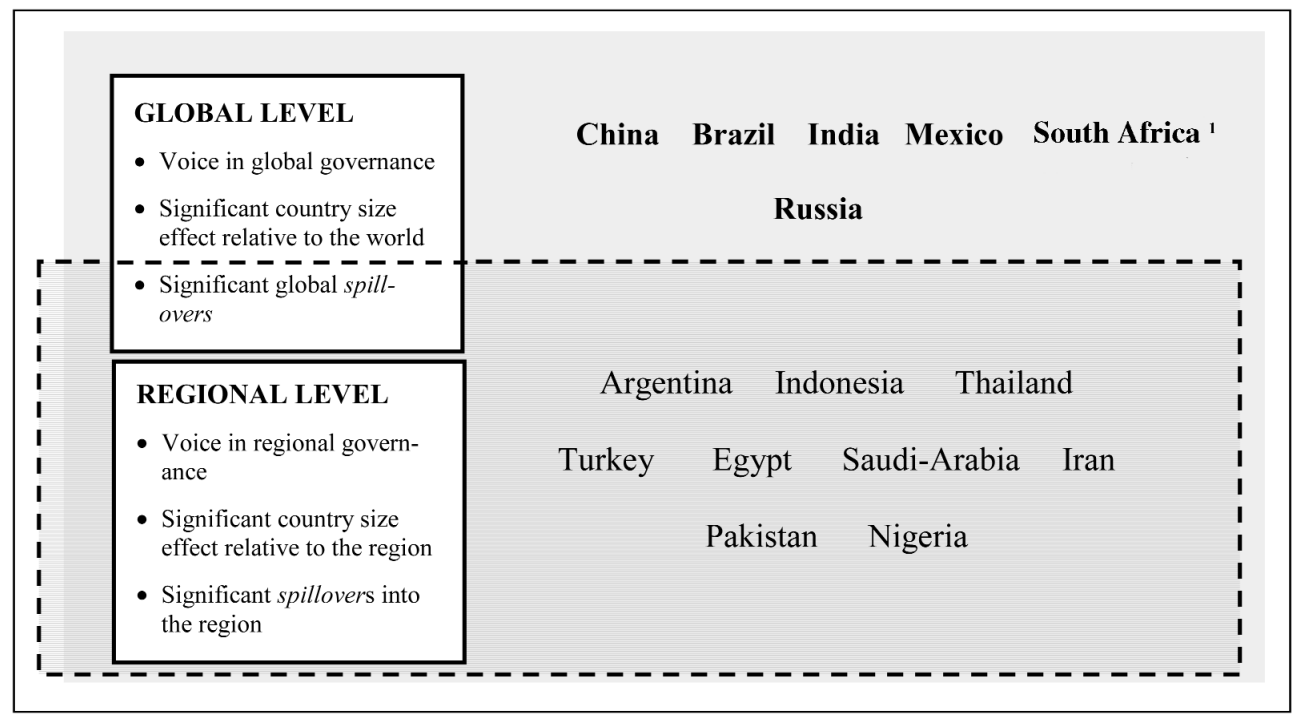

1 South Africa belongs to the group of anchor countries that do have a voice in global governance, whereas its country size does not have particularly important country size effects.

Source: own compilation 
Tab. 1: Anchor countries (AC): their role in selected policy fields

Global policy $A C$ 's material share of field global problems
Global regimes and institutions to regulate these problems

Climate regime of United Nations, especially UN

Framework Convention on Climate Change (UNFCC)

United Nations Environment Programme (UNEP) below the level of industrialized countries

Energy Increasing energy insecurity due to growing economies: Growing economies of G5 consume one fifth $(21.9 \%)$ of electricity worldwide.

Inter alia International Energy Agency (OECD); Organization of the Petroleum Exporting Countries (OPEC)

World Trade Organization (WTO) countries in world trade system hampered due to deadlock of international trade negotiations:

Brazil and India took leading role as speakers of the developing countries which challenged industrialized countries in the still unfinished "Doha Round" in 2003.

Finances

Security
Risk of crises of international financial markets: China has largest stocks of foreign exchange worldwide (1.3 billion US\$), in large parts invested in US state bonds. India also accumulates high reserves.
Weapons of mass destruction (WMD):
AC dispose of more than 50
$\%$ of worldwide WMD; thereof five of nuclear bombs.
Nuclear Non-Proliferation Treaty of 1970 (NNPT) International Atomic En- ergy Agency (IAEA)

International Monetary
Fund (IMF)
G8
Examples of $A C$ 's role in regimes and global institutions

AC - mainly Brazil, China \& India as "speakers" of the "South"- ascribe main responsibility for climate change to industrialized countries due to their high per capita consumption and underline ACs' right to industrialize.

AC adopt more active foreign energy policies and redefine policies in function of their energy import requirements. Bilateral arrangements prevail. Risk of geopolitical conflicts arising from competition for resources.

AC oppose the industrialized countries' (IC) claim for further liberalization of imports of goods and services from IC to the developing world. In turn, developing countries demand that IC should open their market for agricultural and textile goods from developing countries.

China increasingly powerful in international economics due to interdependence with US market. International financial regulation through IMF is limited because China challenges the IMF which it does not consider representative due to outdated quota system.

Partial non-compliance of AC such as India, Pakistan; maybe also Iran. 
tries will continue to grow at above-average rates, so that their share in global production will increase significantly, e.g. "India's economy could be larger than Japan's by 2032, and China's larger than the US by 2041." (WILSON/ PuRushothaman 2003, 4). By 2050, none of the European economies would be among the six largest economies of the world (ibid.).

\section{Economic spillovers from increased trade and investment}

Given the relatively large size of their economies compared to their respective world regions, economic development trends in anchor countries impact significantly on the global economy, and on neighbouring countries within their regions in particular. The recent extraordinary growth of some of the largest economies - particularly China, India and Russia, but to a lesser extent also Argentina, Nigeria, Pakistan, Russia, Thailand, Turkey, and others - has therefore much stronger economic spillover effects than high growth episodes in smaller countries would have. Again, China has by far the strongest impact, not only due to its country size and unique long-term hyper-growth, but also because of its strong export orientation. China's economy accounted for only $2.9 \%$ of global GDP in 1978, increasing its share to $4.7 \%$ in 2004 and, according to projections, will account for as much as $7.9 \%$ by the year 2020 . China's exports grew from 50 billion US\$ in 1990 to more than 1,000 billion today (Gu/ HUMPHREY/ MESSNER 2008).

Economic spillovers from anchor countries result from expansion on the demand and on the supply side. On the demand side, spending power concentrates in anchor countries at a dramatic pace. In a study on Brazil, Russia, India and China (the BRIC), WILSON/ PURUSHOTHAMAN / FIOTAKIS (2004, 2 ff.) calculate that the number of middle class consumers with an income over $\$ 3,000$ should double within three years in these economies. Within a decade over 800 million people will have crossed this threshold, while in 20 years there could be about 200 million people in these economies with incomes above $\$ 15,000$. Never in history has such an increase been observed in terms of gross addition of numbers to the ranks of the consuming class. This will result in greatly increased demand, e.g. for consumer goods. China is projected to become the world's largest car market within 20 years, and
India will become the second largest 15 years later. Global companies therefore increasingly reorient their strategies away from the (relatively) declining old industrialized countries to those of the dynamic anchor countries. This is reflected in increasing trade with, and increased foreign direct investment (FDI) in anchor countries, e.g. in 2005213,5 billion US \$, which are $22 \%$ of the world total.

Demand also increases for energy and mineral resources. This is particularly relevant for resource-rich developing countries. In fact, the strong increase in imports - China's energy demand is expected to double by 2015 , and India's to increase by $50 \%$ (KAPLINSKY/ MESSNER 2008) - has already driven up global commodity prices, which in turn resulted in stronger economic growth in the developing world. Both Africa and Latin America have, in the last four years, achieved significantly higher economic growth than ever since the 1970s. Natural resource exporters have benefited the most.

On the supply side, consumers in the rest of the world benefit from cheaper imports, e.g. of textiles from China. Similarly, multinational corporations can source inputs at lower costs e.g. IT-services from India - and thereby increase their competitiveness. At the same time, increasing exports from China and other lowcost large-scale producers greatly increase competition for established producers, both at home and in third markets. This is a serious challenge for industries that compete directly with products from anchor countries, from small-scale footwear producers in Honduras to electronics manufacturers in Hungary and software developers in Germany.

Adding to these trade effects, companies from anchor countries increasingly invest abroad. This is a rather new phenomenon. In 2005 the 15 anchor countries had invested 373,5 billion US\$ abroad, compared to a modest 118.1 billion in 1995. Russia, Brazil, China, South Africa, Mexico and Argentina all had foreign direct investments above 20 billion US\$. In 2007, according to Fortune Global 500, 40 of the 500 largest companies of the world were based in China, India, Brazil and Mexico (http://stats.unctad.org/FDI/, 9.1.2008; http:// money.cnn.com/magazines/fortune/global500/2007/countries/US.htm, 9.1.2008). Investments in oil and gas played an important role, but the sectoral composition of outward 
FDI also reveals the growing competitiveness of multinational corporations from developing countries in manufacturing and service industries. For example, Brazil's Embraer is today the world leader for regional jets; China's Johnson Electric is the world's largest producer of small electric motors; Bharat Forge from India is the second biggest forging company; China International Marine Containers Group accounts for $50 \%$ of the marine container market; Mexican Cemex is among the largest cement producers (Boston Consulting Group 2006, 5).

The economic spillovers have a strongly differentiating impact on other countries, e.g. depending on whether the latter are mainly competitors or suppliers of complementary goods. In addition, they enhance structural change within other countries. European producers for example are increasingly forced to abandon knowledge-extensive consumer goods and shift towards more innovative products that cannot yet be supplied by anchor countries. Developing countries have an incentive to shift from manufacturing, where competition becomes more fierce, to export production of raw materials. The geographic implications of such shifts within and between countries are unprecedented in recent history and not yet well researched.

\section{Industrial upgrading and its challenges for OECD countries}

From the perspective of the early industrializers of the Triad, the rise of anchor countries creates a strong challenge to step up their efforts in science, technology and innovation. Some of the anchor countries, particularly Brazil and China, have made some progress in shifting from standardized manufacturing and outsourced low-cost activities to building knowledge-based competitive advantages (ALTENBURG/ SCHMitz/ StAMm 2008). This is particularly true for China, which increased its share of high-technology exports in total exports from 7.9 to $29.9 \%$ between 1996 and 2005 (OECD 2007,14). China is now spending $1.3 \%$ of its GDP on research and development (R\&D), having doubled this percentage in less than 10 years. In absolute terms, China is already one of the biggest spenders of $R \& D$ worldwide, and spending increases much faster than in the EU (ibid. 23). The number of researchers is at the same level as that of the EU 25 and second only to that of the United
States (HuAng/SoEte 2007, 9). Also in India, 350,000 engineering graduates are released to the labour market each year (Bound 2007, 9). In response to this, Western multinational corporations increasingly shift knowledge-based operations to China and India, where they established about 750 , respectively $100, R \& D$ centres within a few years (UNCTAD 2005). At the same time, companies from anchor countries are increasingly going global, in many cases acquiring Western companies with their technological expertise and patent rights, and establishing their own global brands, thereby challenging companies in the EU ( $\mathrm{Eu}$ ropean Commission 2004, 272).

Despite their rapid progress, thus far only few anchor country firms or clusters of firms are seriously challenging knowledge-based competitive advantages of the old industrialized nations. However, they do already create pressure to intensify innovation efforts in order to upgrade into high-technology fields that are sheltered from price-based competition from the emerging economies. Furthermore, multinational corporations purchase more knowledge-based inputs from anchor countries, thereby developing new spatial patterns of value chain organization.

\section{The role of anchor countries as security players}

In a similar way, anchor countries are increasingly important players in international security politics. They have been increasing their material basis of military action since 1990; i.e. their military expenditure has been increasing in line with their economic growth (see Tab. 2). In some cases this material increase goes along with a more active political engagement in international security politics. Against this background four global trends can be identified:

1. More than $50 \%$ of existing weapons of mass destruction (WMD) are located in anchor countries, including nuclear arms. By further increasing their stocks of WMD they are contributing to further endanger world peace. This applies especially to anchor countries of South Asia (India, Pakistan) and the Wider Middle East.

2. Small arms are a major global problem, which is also caused by anchor countries. 
They are significant holders as well as producers of small arms on the global range, especially in Latin America and Africa.

3. Anchor countries also help to maintain world peace. On the one hand they have an exceptional share of contributions to UN peacekeeping. It is remarkable that India and Pakistan endanger a whole region by their nuclear arms race, while being the largest personnel contributors to UN peacekeeping. On the other hand anchor countries are engaged in regional security integration, e.g. South Africa and Nigeria contribute relevantly to the African security architecture, whereas Thailand and Indonesia are key players in ASEAN's security related integration (HILPERT/WILl 2005, 18 f.; SHELTON 2006, 134).

4. China stands out as a security player because its exponential increase of military expenditure and its foreign policy change unsettle traditional structures of international security policy.

\section{Military Expenditure}

Anchor countries' relevance in global security politics is reflected in their sizeable share of global military spending, which amounts to $16.8 \%$. Given the fact that the USA covers nearly half of the military expenditure worldwide $(45.7 \%)$, the 15 anchor countries spend one third of the remaining $54.3 \%$ share of global military expenditure, which is spent by 191 states. China, Russia, Saudi Arabia and India are part of the ten, Brazil of the 15 largest military spenders (SIPRI 2007, App. 8A). ${ }^{4}$ Within the country group especially Iran and Saudi Arabia have increased their military budget substantially since 1990 (see Tab. 2), at the same time the share of military spending of their respective national GDP decreased. South Africa constitutes an exception because it reduced its military spending during the period of post-Apartheid (1994).

When it comes to military expenditure, China again trumps the other anchor countries. Although China has always been one of the major military powers in world politics, it recently goes ahead by overtaking the former world power Russia, which has had the second largest military budget until 1998. The Asian dragon has more than doubled its military spending between 2000 and 2006. This increase of military financing is accompanied by a geopolitical reorganization of China's

Tab. 2: Anchor countries - military expenditure (in Mio. \$US)

\begin{tabular}{lrrrr} 
& 1990 & 1995 & 2003 & 2006 \\
\hline China & 13,200 & 15,000 & 36,600 & 49,500 \\
Russia & $* 171,000$ & $* 21,700$ & $* 25,100$ & $* 34,700$ \\
Saudi Arabia & 18,112 & 13,090 & 18,944 & 29,032 \\
India & 12,036 & 12,550 & 18,664 & 23,933 \\
Brazil & $* 9,964$ & $* 11,882$ & 11,979 & $* 13,446$ \\
Turkey & 9,770 & 11,732 & 11,851 & 11,291 \\
Iran & 1,873 & 2,351 & 7,013 & 9,849 \\
Indonesia & $* 2,135$ & $* 2,613$ & 3,319 & $* 3,695$ \\
Pakistan & 3,054 & 3,435 & 4,138 & 4,572 \\
Mexico & $* 1,972$ & 2,901 & 3,336 & 3,136 \\
South Africa & 5,209 & 3,320 & 3,338 & 3,610 \\
Egypt & 2,359 & 2,171 & 2,816 & 2,710 \\
Thailand & 2,484 & 3,240 & 2,077 & 2,045 \\
Argentine & $* 1,832$ & 2,273 & 1,748 & $* 1,847$ \\
Nigeria & 432 & 389 & 784 & 724 \\
USA & 457,648 & 357,382 & 440,813 & 528,692 \\
Global & $1,136,000$ & 855,000 & $1,016,000$ & $1,158,000$ \\
Global share 1 & 22.5 & 12.7 & 14.9 & 16.8 \\
\hline
\end{tabular}

* = SIPRI estimate

1 Decline of the anchor countries' total share of global military spending has its origin in the strong decrease of Russian military spending since 1990.

Source: SIPIRI Data online: http://www.sipri.org, 13.12.2007 
spheres of influence, particularly on the Asian continent. For one thing, China is financing a deep-water port at Gwadar in Pakistan and tries to cooperate with the Burmese military junta to build another port on the Bay of Bengal (KAPLAN 2007). This military growth and reorganisation of geopolitics is widely perceived as a contradiction to China's stated goal of a "peaceful rise" in global politics. Especially the "only superpower" USA perceives its role as military world leader challenged (LEGRO 2007, 515). But for the time being China is still far from reaching Washington's paramount position in worldwide military expenditure and capacities as China's military budget is still eleven times lower than that of the USA (SIPRI 2007). The current challenge lies in the combination of China's exponentially increasing material potential and its recent willingness to take a more active role in global governance on the one hand, and the internationally perceived uncertainty of political intentions in Chinese foreign policy making on the other hand (LEGRO 2007).

\section{Weapons of mass destruction and small arms More than half of the anchor countries dispose of biological, chemical or nuclear weapons, which means between $26,7 \%$ (ballistic mis- siles) and 66,7\% (biological weapons) of all states in possession of WMD (ibid.).}

In the group of anchor countries South Asian and the Middle Eastern states stand out with regard to WMD, especially nuclear weapons (see Tab. 3). China and Russia possess nuclear weapons as declared by the Nuclear Non-Proliferation Treaty (NNPT) of 1970 (both belong to the five "nuclear weapons states" as declared by this treaty). Two others, India and Pakistan, are nuclear powers without being members of the NNPT regime (Israel counts as another nuclear weapon state, not engaged in the NNPT regime). After 1998, when India conducted first nuclear tests, it has been continuously increasing its arsenal of WMD, including nuclear weapons (MüLLER/RAUCH 2007). India defends this nuclear strategy by referring to its neighbouring nuclear powers, China and especially Pakistan. The latter already has gone to war with India three times over the question of the border region Kashmir (1947-49; 1965; 1971). This continuing hostility has lead to a nuclear arms race between India and Pakistan. Since both countries did not agree to subordinate their armament to the
NNPT, Indo-Pakistani relations endanger the whole region and hinder international nuclear control. Uncritical US support to both countries aggravates this situation. Moreover, Pakistan has widely delivered technological knowledge on the construction of nuclear weapons to Libya, Iran and North Korea. Since controls are lacking, it cannot be excluded, that terrorists get access to knowledge and material for constructing nuclear bombs (BUNN/WIER 2000). In respect of India's other traditional regional rival China, it has explicitly let off its rhetoric that China constitutes a major threat to India's security. Although Indian-Sino (trade) relations are improving since Chinese president $\mathrm{Hu}$ Jintao visited Delhi in November 2006 - the first visit of a head of state in one decade - there are still major discrepancies between both nations. China disapproves India's constant military modernization, e.g. India launched a major naval build-up in recent years, also acquiring key naval platforms from Russia, an ally of China. Furthermore, both countries are the first and second largest importers of conventional weapons from 20022006; China with $13 \%$ of world imports, followed by India $(9.5 \%) .5$

Anchor countries of the fragile Wider Middle East stand out because of their above-average stock of WMD: Egypt, Iran, Turkey and Saudi Arabia have gained the ability to make use of WMD (Tab. 3). ${ }^{6}$ One of these countries differs from this group due to its global role in nuclear politics: Iran has long been suspected to maintain a nuclear research program in order to develop an atomic bomb (North Korea is also suspected to develop nuclear weapons). Although this suspicion was disproved in December 2007, Iran's credibility in international politics is still at stake. Iran is more and more turning out as a power capable to polarize world politics due to its ideological conflict with the USA, whereas Russia is one of its supporters. In short, Iran's capability to influence global power constellations is extraordinarily high (VAKAL 2005).

Compared to Asia and the Middle East, WMD are no particular issue in Sub-Sahara Africa. Actually, South Africa makes now use of its non-permanent seat in the UN-Security Council (2007-2008) to promote non-proliferation by stressing the African Nuclear-WeaponFree-Zone Treaty (Treaty of Pelindaba; STоTT 2007, 1). Notwithstanding this exemplary ini- 
tiative for disarmament, South Africa remains one of the largest exporters of small firearms, supporting some of the most lasting conflicts such as Colombia, Israel, and Pakistan (Could/Lam 2004, 144).

Since Argentina and Brazil had abandoned their plans to further develop their nuclear research programs in the 1990 s, neither nuclear weapons, nor other WMD imply major security issues in Latin America. But this fact should not belie the problem of small firearms: Brazil, Mexico and Argentina have a considerable share in proliferation of small firearms due to their high demand of these weapons. Except Egypt, Indonesia, Nigeria and Russia all other anchor countries also can be found in the group of 30 largest holdings of small arms (Small Arms Survey 2007, 47).

\section{Engagement in UN peacekeeping}

Military resources may not only be used to endanger, but also to protect world peace by contributing to UN peacekeeping missions. In line with their increasing role in global politics, anchor countries greatly augmented their contribution to UN peacekeeping missions, allocating $34.5 \%$ of the whole personnel in 2007 (Tab. 3). South Asia stands out when it comes to support UN peacekeeping. Pakistan, Bangladesh and India are the three largest personnel contributors to UN peacekeeping missions. Whereas these countries "traditionally" contribute, Indonesia has only recently intensified its global engagement for peacekeeping. While India's and Pakistan's personnel contributions are commensurate with the growth rates of their respective military expenditure over time, Indonesia excels: The increase of personnel contribution exceeded by far the growth of its

Tab. 3: Anchor countries' personnel contributions to UN peacekeeping (PKO)* and nuclear weapons

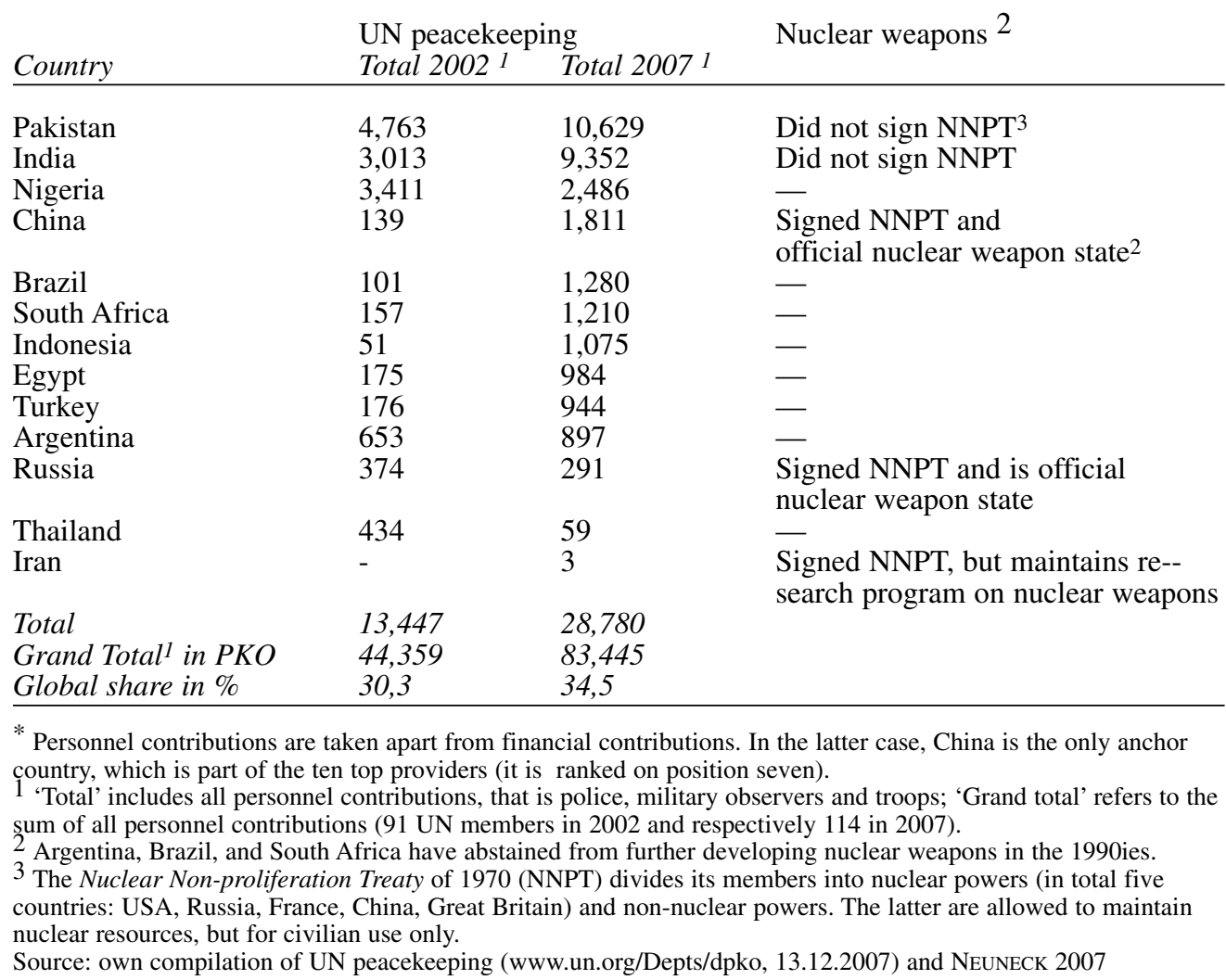


military expenditure. While military spending increased by the factor 1.6 to 1,075 mio. \$US (2000-2006), personnel contributions grew by the factor of 20 in the same period. ${ }^{7}$

Also the Chinese personnel contribution grew 13 times to 1,811 mio. \$US. In Africa, Nigeria stands out as the ninth largest personnel contributor to UN peacekeeping, even surpassing France as the traditional European nation supporting UN peacekeeping. Nigeria also supports sub-regional multilateral efforts to keep peace in West Africa, e.g. the ECOWAS Cease-fire Monitoring Group in Liberia (19901999) and Sierra Leone (1997-2000)(ENGEL 2007, 15). Anchor countries of the Wider Middle East and the Maghreb underperform with regard to their contribution to multilateral engagement in UN peacekeeping missions. Iran and Saudi Arabia almost completely abstain from personnel contributions to UN peacekeeping; Egypt and Turkey have emphasized their responsibility with regard to multilateral engagement for world peace by quintupling their personnel contributions.

\section{Anchor countries - a challenge for global governance}

Anchor countries are steadily and in some cases even exponentially increasing their material power resources - a fact proven in the analysis of their economies and security policies beforehand. In theory such significant increases of economic and military resources of nation states are accompanied by a behavioural change in international relations. An assumption that also fits anchor countries (Gu/MESSNER/HUMPHREY 2007). Anchor countries more and more aim at recognition of their increasing resources of power by taking more active roles in global governance (WILSON/PURUSHO THAMAN 2003; HARRIS 2005). Consequentially, they are building new coalitions with other states in order to increase their bargaining power within or beyond established international institutions. Thus, anchor countries challenge institutions of global governance. In turn, this influence mostly entails the need to reform international institutions and sometimes fosters the creation of new ones. Moreover, it may cause a decline of international institution's relevance in global politics (Fig. 3). In the following, attention will be exemplarily drawn to recent developments of new coalitions between and initiated by anchor countries as well as their impact on international institutions in global economic and security governance.

Shifts of economic spaces: New coalitions, global and regional institutions

Global economic and financial governance has so far been dominated by a northern "club of the few", G7, respectively G8, the international financial institutions (IMF, World Bank) and WTO. ${ }^{8}$ In the 1970 s G6 was established to facilitate dialogue on economic cooperation. At that time first six, than seven states were considered to be the major global economic players - Canada, France, Germany, Great Britain, Italy, Japan, and USA. In the 1990s it evolved

Fig. 3: New coalitions of power and their effect on global governance institutions

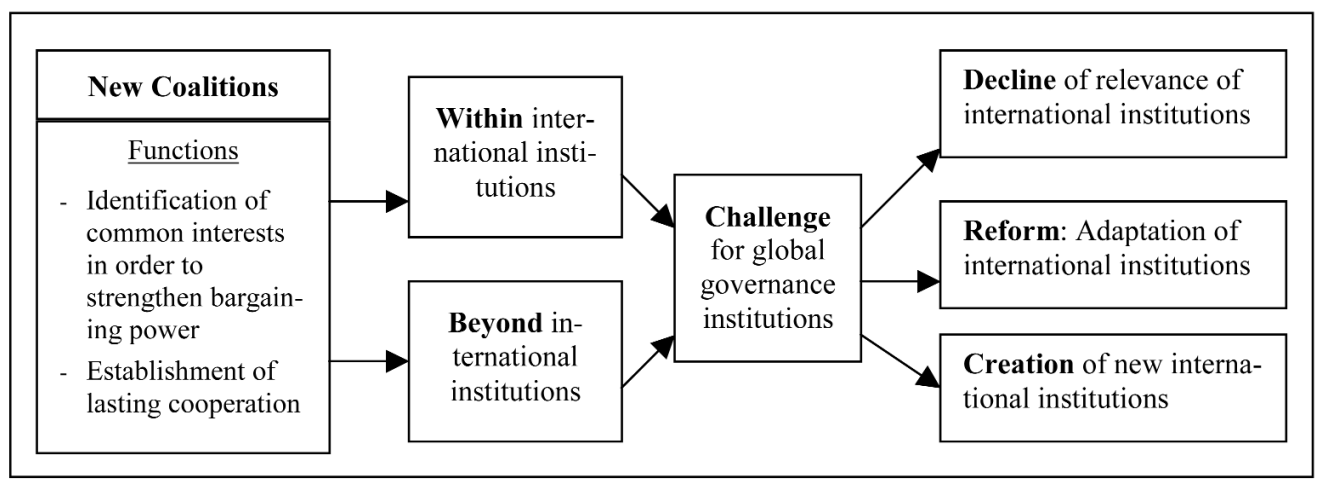

Source: own compilation 
to G8, being enlarged by Russia. Since its time of creation G7 has evolved effectively to a crucial forum for international agenda-setting and decision-making on global economic and lately also on more general issues (GsTöHL 2007, 32 ff.; LESAGE 2007, 113; on the history of creation of G7/8 see GsTÖHL 2007). But during the last years critics have claimed that G8 lacks to represent emerging economic powers and developing countries. Against this background a renovation of North-South relations turned up: First, in 1999 G8 reacted to the financial crisis in Asia, Russia and Brazil by inviting twelve Southern and Northern nations of systemic importance for the financial system to build G20 (finance). Nine out of ten Southern states of G20 (finance) are anchor countries. In short, G20 (finance) came into being as an informal forum to promote dialogue on financial issues between South and North. Secondly, economically emerging anchor countries also question G8's legitimacy. Although convinced of their legitimacy to decide upon issues of global interest, G8 members somehow give partial reason to its critics. In 2005 it started to recognize the increasing economic power of five non-G8 members, namely the G5 (Brazil, China, India, Mexico, and South Africa) - formerly known as O5 = Outreach 5 , taking the enlargement-perspective of the G8. - by inviting them to the annual G8 meetings on an informal basis. Some members, e.g. Great Britain, went even further and suggested that G8 should be enlarged to G13 (LESAGE 2007, 114). In 2007 Germany's G8 presidency focused on improving the cooperation with anchor countries. As a result G8 and G5 established the "Heiligendamm process" in order to embark on results-oriented dialogue on four global issues: innovation, investment, development in Africa, science and technology (GNATH 2007, 38). In autumn 2007 the "Heiligendamm process" was institutionalized at headquarters of the Organisation of Economic Cooperation and Development (OECD).

Emerging economies have not only led to a change of North-South relations, but also to a renovation of South-South constellations. In August 2003 another $\mathrm{G} 20^{9}$ was formed in order to create a block of developing countries in international trade negotiations of the Doha Round in Cancún, Mexico (see Tab. 1). Then, developing countries would not accept a draft proposal of the EU and USA, which claimed lower tariffs on industrial imports into developing countries, while tariffs on agricultural imports from developing countries should be maintained. This proposal catalyzed interests of diverging states such as China, Guatemala and Pakistan. Hence, Brazil initiated G20 and jointly with India, China ("the Big Three") and South Africa has taken a leading role to hold this group together. Although positions of singular states diversified since then, the two opposing blocks persist.

Informal block building in economic areas increased the anchor countries' claim for a stronger role in global economic governance further and challenges global governance institutions. First of all some anchor countries are calling for reform of international institutions. For instance, the International Monetary Fund's (IMF) role as a central rule-making global financial governance institution has been declining due to its quota system of 1946. Various initiatives already have been undertaken in order to reform the quota system. IMF quotas influence votes and, thus, the organizational structure of the institution. European states and the USA are still overrepresented in the IMF executive board and have a factual veto power. Anchor countries, especially China and India, claim an adaptation of the quota system to the current global financial reality. Since only slight reforms have taken place, most economically powerful anchor countries reject the IMF's role as a forum for global financial governance. The World Bank constitutes another example of a declining international institution, e.g. China outruns the World Bank with regard to the extension of loans to African states and, thus, undermines the World Bank's influence as a global economic governance institution.

New South-South coalitions and networks emerge in global economic governance. First, African-Asian ties have been formalized and strengthened through the China-Africa Summit of December 2006 and the New Africa-Asia Strategic Partnership (NAASP). Whereas the former was a high level meeting of African heads of state with Chinese officials in Peking in order to guarantee Chinese financial support to African states (5 billion \$US in 2007), the latter is of normative nature. Inspired by the Bandung Conference, NAASP aims at a more prosperous and peaceful world. It serves as a forum for Asian and African developing countries, whereas Indonesia takes a leading role. NAASP also implements economic projects in its participating countries. 
Second, the current example par excellence for an emerging re-configuration of South-South relations in global governance is the inter-regional IBSA Forum Dialogue, which was created in 2003 by India, Brazil and South Africa (for a detailed analysis see CHEVALIER/ DRACHENFELS/STAMM 2008): "[It can] be characterized as both a strategic alliance for the pursuit of common interests of developing countries in global institutions but also as a platform for bi-, trilateral and interregional South-South cooperation." (FLEMES 2007, 6). That is, IBSA mainly functions as a forum for political coordination amongst India, Brazil, and South Africa, aiming at coalition-building in "the South" in order to create common positions on global issues, particularly on trade, energy security and transport as well as to strengthen cooperation between these countries. In many ways this acclaimed coalition signifies a formalization of existing biand trilateral relations in trade and finance between India, Brazil, and South Africa. However, an effective strategic partnership is still missing (JoHn DE SOUSA 2007, 7).

Shifts of security spaces: New coalitions, global and regional institutions

In global security policy one of the most prominent examples with regard to adapting an international institution to de facto power status of anchor countries is the UN Security Council. In 2005 five anchor countries Brazil, Egypt, India, Nigeria and South Africa - actively promoted the reform of the Security Council and claimed a permanent seat in this central and exclusive UN organ, which still reflects "rusty" power structures from the end of World War II (HellmanN/Roos 2007). India and Brazil along with Germany and Japan represented the G4, which lobbied for UN Security Council enlargement. All anchor countries which aimed at a permanent seat failed due to missing regional support. No world region could agree on one or two "regional powers", which would represent regional matters in the UN Security Council: India's and Japan's positions were opposed by China, which feared its regional power status at stake. Germany was objected by another European state, namely Italy. Brazil met a very strong opposition of two other anchor countries, Argentina and Mexico. Insurmountable obstacles also appeared, when it came to name one or two African countries. All African anchor countries, Egypt, Nigeria and South Africa claimed a permanent seat and would not - as G4 - agree on other models of representation, e.g. rotating, regional permanent seats (for an overview on the reform process see MALONE 2007). In short, UN members could not agree on reforming the UN Security Council in 2005. Although, the whole process also has a positive implication: UN Security Council reform brought the issue of power shifts in international relations openly onto the agenda of global politics, which initiated a public debate on these shifts. This matter of fact is underlined by the anchor country's attempts to foster their global role through coalition building in multilateral groups. For instance, Brazil's, India's and South Africa's ministers of defence agreed on a security agenda within the scope of their IBSA Dialogue Forum in 2004.

On the regional level the creation of new structures and institutions for security cooperation can be observed. Against this background one outstanding example is the Shanghai Security cooperation (SCO), which was the first international organization initiated by China in 2001 (Gu 2007, 372). In 2003 member states (China, Russia, Kazakhstan, Kyrgyzstan, Uzbekistan and Tajikistan) signed a treaty to institutionalize SCO and thereby foster its main objectives, that is structuring geopolitical and security interests in Central Asia. Since than this formal institutionalization was backed by military and political activities of members states, e.g. military field exercises of all member states in August 2003 or the creation of the "SCO Regional Antiterrorism Structure" in Tashkent. One of the major impacts of SCO can be seen in its impact on SinoRussian relations, which are given new ground and are qualitatively deepened (BAILES / DunAY 2007, 2). Thus, up to now, SCO hindered confrontation of China and Russia in their common space of influence Central Asia. $\mathrm{SCO}$ - just as any other regional cooperation fulfils national interests of its members. Especially China initiated SCO in order to achieve national interests: Firstly, due to its exponential economic growth China is dependent on oil imports. Initiating SCO constituted one Chinese strategy to diversify its oil imports (Gu 2007, 372). By winning Russia and Central Asian partners to cooperate on security issues, China intended to show its capacity to "...build an international bloc independent of the West and organized on non-Western principles" (BAILeS / DunAY 2007, 13). Moreover other states of the region have been attracted 
by SCO. Hence, diverse states as Iran, India, Pakistan and Mongolia obtained observer status.

Whereas African and Asian anchor countries are actively pushing integration of regional security cooperation mechanisms, Latin American anchor countries Brazil, Argentina and Mexico focus on unilateral security initiatives due to a prevailing North-South divide in the Americas. Particularly, Brazil - to some extent also Argentina - focus on conflict resolution through mediation in South American conflicts, e.g. in the case of Paraguay and Venezuela Brazil played an important role as a regional mediator (SCHIRM 2007, 11). Moreover, as the attempts to reform the UN Security have shown, Brazil is strongly oriented to the global space when it comes to security issues. On the global level Brazil refers to its leading regional role, although its claim for regional leadership is opposed by Mexico and Argentina.

\section{Outlook: Research challenges for economic geography}

The previous chapters have shown that the new global power shift changes the principles and processes of resource allocation worldwide, and thus also the resulting spatial patterns of societal organization. Thus it creates a wide array of questions and challenges for economic geography. Long established mind maps and concepts need to be thrown overboard. Inherently geographic concepts, such as North-South relations, or the Triad-concept, are losing analytical value. Centre-periphery relationships need to be redefined. The traditional pattern of global division of labour, where industrialized countries are exporting manufactured goods and bring in raw materials has already changed. Manufactured consumer goods now overwhelmingly come from Asia. More recently, even technology-intensive goods and services are being produced on the basis of proprietary technology in anchor countries and exported to the old industrialized countries - e.g. aircrafts from Brazil and software from India. More often, however, global value chains under the coordination of Western multinationals combine competitive advantages of OECD and anchor countries, thereby enhancing global trade integration. Within such value chains, corporations more and more often shift $\mathrm{R} \& \mathrm{D}$ centres to China and India.
As patterns of value chain organization become more complex, new regional production networks emerge, some of them at a large spatial scale. For example, an emerging pan-Asian production system combines advanced components and capital goods from Japan, Korea and Singapore with simple inputs coming from other Asian economies; assembly takes place in China, but is more and more often supported by local R\&D centres; and logistics services are located in Singapore or Hongkong (UNCTAD 2006, 14). These new patterns challenge established Western producers at all stages of the value chain - not just the low-cost assembly operations. Furthermore, geographic location in relation to such production networks greatly influences the development opportunities of countries. The fact that Vietnam, for example, is among the most rapidly growing economies of the world - despite anachronistic forms of economic governance by a communist party and a considerable percentage of state-owned enterprises - can largely be attributed to its favourable location amidst the worlds most thriving economic region. Yet so far few geographers have studied the local, regional and global implications of these emerging networks.

In a similar way, political and military power blocs and alliances are changing. New regional powers are challenging the USA as a the previously undisputed hegemon. New South-South alliances emerge and new global institutions are challenging the industrialized countries dominance in institutions of global governance. The analysis has also shown that economic, political and military power shifts are interdependent. For example, economic growth heightens the importance of energy security, which in turn determines the emerging countries' foreign policies, military alliances, and their stance with regard to global institutions.

These interdependencies and the resulting global power shifts are increasingly attracting the attention of researchers from economic and political sciences. The rise of anchor countries however also opens up an extensive new research agenda for economic geographers. For example, further research is needed to explore the differential impact of the economic and political rise of anchor countries, both in other developing and in industrialized countries. Likewise, geographers may bring in new perspectives to analyze the interconnectedness of different spatial scales, e.g. how local and national climate 
change action correlates greenhouse gas emissions and the political stance of anchor countries with regard to global climate governance.

\section{Notes}

1 Note that the concept of anchor countries is defined dynamically, and the composition of the group may vary accordingly. At the time of writing Saudi Arabia stands on the classificatory threshold line between Upper Middle Income Countries and High Income Countries and may therefore graduate from the DAC list of developing countries. Algeria joined the group because it passed the threshold value of $20 \%$ of regional GDP.

2 Whereas the concept of anchor countries has a structural nature, other notions are functional in order to operationalize specific phenomena as power hierarchies in international relations (e.g. middle power, great power; COOPER 1997), regional leadership (e.g. regional power, NOLTE 2006), the potential influence of regional powers on global politics (e.g. intermediate state; HURRELL 2000) or conflict and cooperation in international relations (KUGLER 2006).

3 Our research focus is on newly emerging powers from the developing world. Russia is outside this research focus due to its longer history as a military and political superpower. The remaining "second level" anchor countries are referred to wherever they are significant to the particular policy field which is analysed.

4 Counting military expenditure in Power Purchase Parity includes Iran, Pakistan and Turkey into to list of the 15 largest spenders.

5 The list of the 10 largest exporters of major conventional weapons is headed by the USA $(30.2 \%)$ and Russia (28.9 \%) (Stockholm Peace Research Institute 2007, 17).

6 Other states disposing of weapons of mass destruction are the five members of the UN Security Council, Israel, North Korea, Syria, South Korea, Libya, Albania (NEUNECK 2007, 129)

7 In total UN peacekeeping personnel (civilian police officers, military observers and troops) has nearly doubled in the same period of time, that is from 44,359 (2000) to 83,445 (2006).

8 IMF, World Bank and WTO are international institutions with a wide range of members, but they have been dominated by industrialized countries of the "North".

9 G20 (Cancún) of developing countries already surpasses 20 members and therefore, is also called G20+.

\section{Literature}

Altenburg, T./Schmitz, H./Stamm, A. (2008): Breakthrough? China's and India's transition from production to innovation. In: World Development, (36)2, 325-344.
BAILES, J.K./Dunay, P. et al (2007): The Shanghai cooperation organization. Stockholm. (SIPRI Policy Paper No. 17).

Boston Consulting Group (2006): The new global challengers. How 100 top companies from rapidly developing economies are changing the world, Boston, M.A.

Bound, K. (2007). India: the uneven innovator. London.

BunN, M./WIER, A. (2005): Securing the bomb. The new global imperatives, commissioned by the Nuclear Threat Initiative. Internet: (http://www.nti.org/e_research/cnwm/cnwm.pdf, 3/2005.

Cooper, A. F.(Ed.) (1997): Niche diplomacy. Middle powers after the cold war. Basingstoke.

Cooper, A. F./Antkiewicz, A./Shaw, T. (2006): Economic size trumps all else? Lessons from BRICSAM. Waterloo. (Working Paper Emerging Economies No. 12, (Dec. 2006, The Centre for International Governance Innovation).

Could, C./LAM, G. (2004): Hide and seek: Taking account of small arms in Southern Africa. Durban.

Deutsche Stiftung Weltbevölkerung (2007): Weltbevölkerung 2007. Göttingen.

ENGEL, U. (2007): Entwicklungszusammenarbeit mit Nigeria - eine Analyse aus der Ankerlandperspektive. Bonn. (DIE Discussion Paper 13/2007).

European Commission (2004): European competitiveness report 2004. Luxembourg.

FLEMES, D. (2007): Emerging middle powers's soft balancing strategy. Hamburg. (GIGA Working Paper 57/2007)

Fues, T. (2007): Global governance beyond G8. Reform prospects for the summit architecture. In: Internationale Politik und Gesellschaft, 4, 11-24.

GsTÖHL, S. (2007): Governance through government networks: The G8 and international organizations. In: Review of International Organization, 2, 1-37.

Gu, X. (2007): China und der asiatisch-pazifische Raum. In: Fischer, D./Lackner, M. (Eds.): Länderbericht China. Bonn, 359-278.

Gu, J./HumPhreY, J./MEssner, D. (2007): Global governance and developing countries: The implications of the rise of China. Bonn. (DIE Discussion Paper 18/2007).

HARRIS, J. (2005): Emerging third world powers: China, India and Brazil. In: Race \& Class, (46)3, 7-27.

HellmanN, G./Roos, U. (2007): UN. Von Windhunden und Hasen. In: Internationale Politik, 10, 92-98.

HilPeRT, H.G./WiLl, G. (2005): China und Südostasien. Auf dem Weg zu regionaler Partnerschaft. Berlin. (SWP-Studie, August 2005).

HuAng, C./ SoEte, L. (2007): The global challenges of the knowledge economy: China and the EU. Tokyo. (UNU-MERIT Working Paper Series, 2007-28).

HurRell, A. (2000): Some reflections on the role of intermediate powers in international institutions. In: Hurrell, A./Cooper, A./Gonzalez, F./Ubiraci, R./Sitaraman, S. (Eds.): Paths to power. Foreign policy strategies of intermediate states. Washington D.C. (Woodrow Wilson International Center, Working Paper Nr. 244). 
JoHn DE SousA, S. (2007): India, Brazil, South Africa (IBSA) - New inter-regional multilateralism in the south? Madrid. (FRIDE Peace and Security Human Rights Backgrounder, April 2007).

KAPLAN, R.D. (2007): Asia rising. Lost in the Pacific. In: International Herald Tribune, September 22-23, 8.

KAPLINSKY, R./MEssner, D. (2008): Introduction: The impact of Asian drivers on the developing world. In: World Development, (36)2, 197-209.

Kugler, J. (2006): The Asian ascent. Opportunity for peace or precondition for war? In: International Studies Perspectives, 7, 36-42.

LANDES, D. (1998): Wealth and poverty of nations. Why some are so rich and some so poor. New York.

LEgRo, J.W. (2007): What China will want: The future intentions of a rising power. In: Perspectives on Politics, September 2007.

LESAGE, D. (2007): Is the world imaginable without the G8?. In: Internationale Politik und Gesellschaft, 4, 107116.

Malone, D. (2007): The Security Council. In: Weiss, T. (Ed.): The Oxford Handbook on the United Nations. Oxford, 117-135.

Müller, H./Rauch, C. (2007): Der Atomdeal. Die indisch-amerikanische Nuklearkooperation und ihre Auswirkungen auf das globale Nichtverbreitungsregime. Frankfurt am Main. (HSFK Report 6/2007).

NeunecK, G. (2007): Proliferation und Kontrolle von Massenvernichtungswaffen. In: Globale Trends 2007. Bonn, 123-141.

Nolte, D. (2006): The rise of (new) regional powers in international politics. Research topics and analytical concepts. Hamburg. (Paper prepared for delivery at the conference on "Regional Powers in Asia, Africa, Latin America, and the Middle East", Hamburg, December 11-12, 2006).

OECD (2007): OECD reviews of innovation policy, China. Synthesis report. Paris.

OHMaE, K. (1985): Triad power. The coming shape of global competition. New York.

SchIRM, S. (2007): Ankerland Brasilien: Die Rolle Brasiliens in der globalen Strukturpolitik. Bonn. (DIE Discussion Paper 16/2007).
Stockholm Peace Research Institute (2007): SIPRI Yearbook 2007. Stockholm.

Shelton, G. (2006): South Africa's engagement with the global security agenda. In: Costa VAZ, A. et al <bitte hier alle Autoren nennen!> (Eds): Intermediate states, regional leadership and security: India, Brazil and South Africa. Brasilia, 129-164.

Small Arms Survey (2007): Small arms survey. Guns and the city. Cambridge.

SoARES, M./Hirst, M. (2006): Brazil as an intermediate state and regional power: action, choice and responsibilities. In: International Affairs, (82)1, 21-40.

STAmm, A. (2004): Schwellen- und Ankerländer als Akteure einer globalen Partnerschaft. Bonn.(DIE Discussion Paper 1/2004).

Stott, N. (2007): Testing time for South Africa on nuclear issues. ISS Today. Pretoria.

UNCTAD (2005): World investment report 2005. Transnational corporations and the internationalization of R\&D. New York, Geneva.

UNCTAD (2006): Report of the Commission on Enterprise, Business Facilitation and Development on its tenth session. Geneva.

UNDP (2007): Human development report. New York.

United Nations (2007): UN peacekeeping. Facts and figures. Internet: www.un.org/Depts/pko, 22.10.2007.

United Nations (2006): The millennium development goals report 2006. New York.

VAKAL, S. (2005): Iran - balancing East against West. In: The Washington Quarterly, (19)4, 51-65.

Wilson/Purushothaman (2003): Dreaming with BRICS. Thepath to 2050. New York a.o. (Goldman Sachs, Global Economics Paper No. 99).

Wilson/Purushothaman/Fiotakis (2004): The BRICS and global markets. Crude, cars, and capital. New York a.o. (Goldman Sachs, Global Economics Paper No. 118).

World Bank (2007): World Bank development indicators. Washington D.C. 